\title{
Remoteness, islands and islandness
}

\section{Owe Ronström}

\author{
Uppsala University, Campus Gotland, Sweden \\ owe.ronstrom@etnoplogi.uu.se
}

\begin{abstract}
Through an explorative overview of a number of approaches to what remoteness is, in terms of language, discourse, and fantasy, how it is established spatially and temporally by movements and perspectives, by how connections are set up, and by how boundaries are drawn and crossed, this paper argues that remoteness is a) produced rather than discovered; b) an asymmetric relation between two parties from which emanates certain features, practices, and affective modes; c) a category to think with rather than an object for such thinking; d) a device that frames and structures the positioning and experiencing of time and place; and e) a part of the logic that organises the world in terms of power and control. Of longstanding concern in island studies is what constitutes 'the island'. Much of the discussion is built on an undertheorised and broadly accepted dichotomisation between 'literal' and 'metaphorical' understandings of islands. What the overview suggests is a third position: 'the island' as an intensively multirelational phenomenon constituted by the constant sliding between islands as physical places and all the figures of thought attached to such places.
\end{abstract}

Keywords: Baltic Sea, Gotland, islands, islandness, isolation, periphery, remoteness

https://doi.org/10.24043/isj.162 • Received May 2019, Early access May 2021

(C) Island Studies Journal, 2021

In Atlas of remote islands: Fifty islands I have not visited and never will, the German cartographer Judith Schalansky (2010) explores her fascination for small, faraway islands. All are carefully mapped in great detail, in solitude, as miniature worlds of their own, encompassed by vast empty oceans - and by stories. "The absurdity of reality is lost on the large land masses," Schalansky writes, "but here on the islands, it is writ large":

An island offers a stage: everything that happens on it is practically forced to turn into a story, into a chamber piece in the middle of nowhere, into the stuff of literature. What is unique about these tales is that fact and fiction can no longer be separated: fact is fictionalised and fiction is turned into fact. (Schalansky, 2010, pp. 19-20)

An island, a map, and a story: fifty small chamber pieces in the middle of nowhere. And to that a story of the author's fascination for these islands: 
They are mostly left out altogether, but sometimes they are granted a place at a cartographical side table, hemmed in by a framed box and with a separate scale measure squashed at the edge, but with no information about where they are. They become footnotes to the mainland, expendable to an extent, but also disproportionately more interesting. (Schalansky, 2010, pp. 13-14)

As expendable footnotes these islands may indeed appear when approached one by one. But taken together they coalesce into a larger map, one of disproportionate interest and fascination for the remote. In essence, Schalansky's book is a detailed cartography and exploration of islands and remoteness in which fact and fiction, myth and reality become inexorably blurred.

What follows here is again a cartography of islands and remoteness, a meditation in another key and without maps: ten sections, each with a different perspective, in a rather abstract and generalised mode. The aim is not a coherent picture or story, but rather an exploration without fixed start or end points, much as when the finger follows a river or a coastline on a map.

The perspective is predominantly north European, based on my previous work on islands, and on work by John Gillis, Godfrey Baldacchino, Edwin Ardener, and others. Most examples come from Gotland, my own native island; from Åland and Saaremaa, all in the Baltic Sea; and from Atlantic islands I have visited and worked on, such as the Shetland isles, and Prince Edward Island and Cape Breton in the Canadian Maritimes.

As Schalansky did, I will use islands as focal points, to dwell upon, to depart from, and, perhaps more importantly, to think with. Clearly, remoteness is not a concern only for islands. All sorts of places can become remote(d). Still, islands have long since been a focal point for fantasies of remoteness, to such an extent that remoteness is now a hallmark of islandness, alongside boundedness, smallness, and isolation. Ascribing remoteness to a place, whether surrounded by water or not, is a remarkably effective way to island it.

Of longstanding concern in island studies is what constitutes 'the island', a question that inevitably will lead to where the islands of study are located, in geography, discourse, or both. Much of the discussion is built on an undertheorised and broadly accepted dichotomisation between 'literal' and 'metaphorical' understandings of islands (Dodds \& Royle, 2003; Fletcher, 2010; Hay, 2006; Ronström, 2013). What the following suggests is a third position: simply that 'the island' is constituted by the constant and wayward sliding between the physical places we call islands, and all the figures of thought that we attach to such places. Schalansky is definitely not the only person to become enchanted. Remote islands work well as stages for narratives about distance, difference, and separateness, as well as about nearness, similarity, and unity. And, as Schalansky notes, in such narratives fact and fiction cannot easily, if at all, be separated. It is this unstable, floating capacity that makes islands so attractive to project dreams and fantasies on. Since fantasy and imagination loom large on islands, and since whatever we believe is real tends to have real consequences, island fantasies have a tendency to become consequential facts. Remoteness is, I believe, one of those facts. 


\section{Relations}

A starting point for the mythical geography of the modern era is the idea that special kinds of places create special kinds of people (Edmond \& Smith, 2003). Its consequence is an essentialisation of space that makes geographical, social, and cultural boundaries appear as naturally given: the more distinctive the natural environment, the more distinctively different its population. Thus, inhabitants of wastelands, river deltas, marshes, mountains, and islands are said to develop certain physical characteristics and a special mentality. Such differences are understood to increase with distance, which makes remoteness a difference that makes a difference.

In Island studies such widespread essentialising ideas have been problematised from a number of perspectives. There is a fast-growing body of literature on islands as relational phenomena, in terms of archipelagos, aquapelagos, networks, rhisomes, seriality, and more; a literature that, as Jonathan Pugh notes, "unsettle[s] borders of land/sea, island/mainland, and problematise static tropes of island insularity, isolation, dependency and peripherality" (2018, p. 94). This 'relational turn' in Island Studies Pugh sees as a "concerted effort to radically decentre notions of the static island and instead emphasise mobile, multiple and interconnected relational forms" (2018, p. 94).

Remoteness, I will argue, is one of those forms; it is an intensively multirelational phenomenon. An explorative meditation on remoteness will therefore have to consider distance and peripherality in relation to proximity, nearness, and centrality, and how such positions are reproduced and maintained. It will have to consider how remoteness is produced spatially and temporally, in terms of pasts, presents, and futures, and how this is coupled to power relations. It will further have to consider how remoteness is produced by movements and perspectives, by how connections are set up and how boundaries are drawn and crossed. It will also have to consider remoteness in terms of words, concepts, and metaphors; of imageries, affects, and figures of thought; and, lastly, how all these relational dimensions mould as one naturalised totality.

Such a study will decentre, destabilise, and disrupt the common positioning of islands as faraway, peripheral, isolated, small, and unimportant, and open up for a more complex understanding of how humans relate to the world and of how the world acts upon humans. Through an overview of a number of approaches to what remoteness is, how it is produced, and some of its consequences, this paper aspires to be a small step in such a direction, by arguing that remoteness is a) produced rather than discovered; b) an asymmetric relation between two parties from which emanates certain features, practices, and affective modes; $c$ ) a category to think with rather than an object for such thinking; d) a device that frames and structures the positioning and experiencing of time and place; and e) a part of the logic that organises the world in terms of power and control.

\section{Ways with words: Etymologies and dictionaries}

What is remoteness? A first obvious answer: a word. In a number of European languages, i.e., English, French, Finnish, and Russian, the stem is a word denoting distance, literally a 'faraway-ness'. In another group of languages, i.e., Swedish, German, and Dutch, the stem comprises words that denote a position, an 'off-place-ness'. 
These nuances are mirrored in dictionaries and encyclopaedias. While the Oxford English Dictionary builds on distance, "Remoteness - the state of being distant from something else, in particular from the main centres of population" (n.d.), the Swedish National Encyclopaedia builds on position: "Remoteness - that which is far away, in time or space" (n.d.). To such condensed entries the dictionaries add also a large number of uses and meanings in three main categories: denoting distance in space, in time, and, more figuratively, in relations. Remoteness can thus mean something that is inaccessible, aside, far away, lacks connection, or is out of the way. The second half of the entry in the Swedish National Encyclopaedia is revealing: "Often something that is less known or less interesting" (n.d.). In essence, remoteness is an expression of a hierarchical, unequal, and asymmetric relation between phenomena or places. The dictionaries' lists of adjectives are instructive; what is remote is also often small, scant, dim, obscure, aloof, distant in manner, standoffish, unfriendly, of small value or interest.

In a number of North West European languages, remoteness thus denotes a condition of physical distance, a 'far-away-ness'; and/or a geographical position, an 'off-place-ness' in the real world; and/or a perspective, an affective mode and conceptual phenomenon 'of the mind'. As such, remoteness is an active component of a "mythical geography", or "geosophy" (Gillis, 2004 , p. 17), a worldview that refers to the topography of the physical world but is founded and becomes meaningful in a cognitive topology. Anthropologist Edwin Ardener notes that it is "obviously necessary that 'remoteness' has a position in a topographical space, but it is defined within a topological space whose features are expressed in a cultural vocabulary" (Ardener, 1987, p. 41).

\section{Ways with words: Positions and directions}

Coupled to remoteness is a highly charged semantic field of tension that revolves around dichotomies such as modern-old, development-stagnation, advancement-backwardness, and centre-periphery. Remoteness relies especially on its contrastive relation to closeness, similarity, and familiarity. Similarity is closeness, difference is distance belongs to the primary positional metaphors that give meaning to positions and directions (Lakoff \& Johnson, 1980). Difference and distance become aspects of the same phenomenon, not so much fixed points as positions on a scale: the more distant, spatially and temporally, the bigger the difference.

In many languages in the Western world, proximity/similarity are closely connected to being 'in', a position that entails affiliation, community, and spatial direction: we are 'in' and travel 'in to' our home, family, group, society, or country. Islands belong to the kind of phenomena that you are 'on', and travel 'out to', which entails distance and a different type of relation between subject and object. 'In' is a container metaphor grounded in basic bodily experience: wherever you can be 'in' (a room, a house, or a nation), you can also be 'out', 'outside', 'locked out from', 'foreclosed'. In cases like these, 'in' and 'out' produce a spatial hierarchy. Objects you are 'in' and travel 'in to' are positioned in the centre, and places that you are 'on' and travel 'out to', at a distance (Ronström, 2011).

With a central position comes a certain relation to distance. To travel 'in to', come 'inside', and be 'safely inside' entails a more definite and complete state, a natural place of rest that does not require further explanation or justification. To travel 'out to' and be 'outside' entails not only a more distant and peripheral position, but also an ongoing, indefinite, and 
incomplete movement, being 'far out', on an 'outing', or going 'out to' the countryside or an island. 'In' and 'out' are thus not neutral, but performative devices that both tell of, produce, and evaluate relative distances: while 'in' and 'in to' are related to the near, 'out' and 'out to' are related to distance and remoteness. Islanders I have met in Scandinavia, the British Isles, the Mediterranean, the Caribbean Islands, and Canada typically comment on the peculiar difference in perspective that this way of conceptualising the world brings about. While mainlanders are positioned 'in', islanders are more often 'on' and 'out there'. For mainlanders to travel out to the island seems farther away, more expensive, difficult, inconvenient, and time-consuming than for islanders to travel in to the mainland, just like it seems longer for townsfolk to go out to the countryside than for country people to travel in to town.

\section{Apart or separate}

In his classical essay, "Bridge and door," Georg Simmel (1908/1997) observes that "the human being is the connecting creature who must always separate and cannot connect without separating" (p. 174). Thus, "we can only sense those things to be related which we have previously somehow isolated from one another; things must first be separated from one another in order to be together" (Simmel, 1908/1997, p. 5). In passing, he also notes that humans tend to differentiate between objects that are 'apart' and 'separate'. The difference is important. 'Apart' are things that are scattered around, fragmented, unrelated. 'Separate' are things that in some way are related and normally belong together. While apartness is a "static non-relational statement of fact," separateness is "a dynamic condition that betrays a need for, or interest in, connection" (Baldacchino, 2007a, pp. 3-4).

Geographers commonly categorise islands in a Simmelesque manner: while continental islands are 'separate', being geologically connected to its mainland, oceanic islands are 'apart', standalones formed by volcanic eruptions or coral. This, Gilles Deleuze (2004) argues, confirms what imagination already knows. Continental islands are dislocated fragments, accidental and derived. Born of "disarticulation, erosion, fracture" (Kinane, 2011, p. 48), they are abject, and as "tail-ends" (Kinane, 2011, p. 48) of society they are easily marginalised, or simply displaced and forgotten. Oceanic islands, on the other hand, are created by powerful underground forces. They stand as independent solitaries, originary, authentic, and essential, bringing up to the surface/consciousness charges and movements from unknown, unconscious depths (Deleuze, 2004).

Remoteness operates, I suggest, within this logic of connection, separation, and apartness. 'At home', 'in', and 'nearby', we are principally connected. The separate is already the potentially connected, because, as Simmel puts it, humans are at any moment those who separate the connected or connect the separate (Simmel, 1908/1997, p. 5). Things or places that are 'apart' do not call for connecting activities. Logically, then, the potential of remoteness should increase when we move from 'at home/near', via 'out there' to 'far away, 'separate' and 'apart', and halt only at the 'unattainable', where we can never go, places that, like stars and planets, are remote by name and fantasy but lack the empirical and experiential qualities of remoteness. 


\section{Bridging gaps}

When we connect, we underline what separates; when we divide, we underline what connects. Therefore, it would be meaningless to connect what is not separated. In the bridge, separateness and connectedness "meet in such a way that the former appears more as the concern of nature and the latter more the concern of humankind" (Simmel, 1908/1997, p. 8). Thus, not any space is bridged. A bridge makes sense when it connects things that are separate but not apart, when it unites what could or should already have been connected. Bridges, and fixed links such as airlines, ferries, telephone networks, and internet, are established first and foremost between places that belong together, but for some reason have become separated. Thus, in theory, bridges do not create as much as they restore and improve connections. And so it seems also in practice: a majority of bridged islands have since long had close connections to their mainland centres (Baldacchino, 2007b, 2020).

A bridge is as much a concrete manifestation of connection as of difference and distance. Each time it is crossed, the boundary, the distance, and the connection are simultaneously marked and confirmed (Gillis, 2004, p. 147; Heidegger, 1993, pp. 343-346). Bridges can reduce an island's remoteness and islandness in a number of ways, by reducing the number of means of transport and the time of the transport, and by turning islands into passages: stops on a main road to further destinations. When bridges lead into dead ends and the only way out is to turn back along the same route, the island's remoteness and islandness is more likely underlined. To be able to continue or to have to travel back makes a difference: places along highways may be peripheral in many ways, but they are not as remote as places at the end of the road.

Funen (Fyn) is Denmark's third largest island. Two bridges over Little Belt, built in 1935 and 1970, confirmed and strengthened the old connections to mainland Jutland. In 1998, after years of planning, a bridge over Great Belt was opened, connecting two growing cities, Odense and Copenhagen, and effectively linking eastern and western Denmark. When, in 2000, the Øresund bridge opened, a fixed link was established not only between two metropolitan areas, Copenhagen and Malmö, Sweden, but also between the Scandinavian peninsula and mainland Europe.

Earlier, around 8,000 cars arrived daily to Funen by ferry from Zealand. By 2008, more than 30,000 cars crossed the new bridge each day, in addition to which came a large number of passengers traveling by high-speed trains. The reduction of the number of means of transport and crossing time (from around 90 to less than 15 minutes) has clearly foregrounded Funen's position as a passage, and thereby reduced its remoteness and islandness ("Great Belt", n.d.).

The Swedish island researcher and islomane Anders Källgård (2007) notes that research on bridge effects is scarce, but that a common view is that bridges are good for 'hard' values, such as economy, social development and population growth, but worse for 'soft' life quality values (Källgård, 2007, p. 253; Royle, 2007, p. 203). All of the five largest Swedish islands with a fixed connection (Öland, Orust, Hisingen, Värmdö, and Tjörn) have had positive population development, while the population increased in just one of the five largest islands without bridges (Ljusterö). Källgård's own commune, Varberg, on the Swedish west coast, had four populated islands in the early 1900s. Two of them are now abandoned, one has three inhabitants; while the population of the fourth, Getterön, with a permanent connection since the 1930s, has grown to 200 inhabitants. But then again, it should be remembered that all 
Swedish islands in or near big cities have increased their population-with or without a bridge (Källgård, 2007).

Although 'hard facts' speak for fixed connections, Swedish islanders have voted against bridges on three occasions since 1996. In Fårö, north Gotland, in the middle of the Baltic Sea, the number of permanent residents has decreased since the 1950s. Lack of work and community services drives people away, along with rampant house prices, a direct consequence of the attractiveness that Fårö has long since exercised on the Swedish political and cultural elite. Part of that attraction can on good grounds be assumed to be generated by the relative remoteness that the lack of bridge entails (Pergament, 2007).

Bridging plans have been made on several occasions. In 1990, the Swedish Transport Administration calculated that a bridge would be cheaper than the existing ferry service. An extensive discussion followed. Some Fårö residents, supported by high-voiced summer guests, pleaded for the ferry. Others, supported by parts of the Gotland population, argued for the bridge. In 1996, a vote was held among the around 500 permanent residents. Almost everyone voted. Of the men, $60 \%$ preferred the bridge; of the women, $70 \%$ voted for the ferry. The result was continued ferry service, no bridge.

Over the following years, the population continued to decline and the local shop, health centre, and school closed (Källgård, 2007). In spring 2005, the question was raised again, now in a somewhat new light. The chairman of the association Fårö Future pleaded for a bridge on the grounds that a bridge could reduce the island's attractiveness, which she thought could make real estate prices fall, so it could again be possible for families with children to acquire houses on Fårö: "With the property prices we now have, we will die out, there is no growth in society" (Gotlands Tidningar, 2005). A common pattern: while incomers may oppose a bridge or tunnel, natives can emphasise other values.

As of 2019, Fårö can still be reached only by ferry. A bridge would possibly be cheaper, faster, and more convenient. But to visitors there seems to be a certain attraction in the short ferry ride, building up the excitement towards exploring what's on the other side- otherwise it is difficult to explain why so many visitors voluntarily line up for the ferry in hot summer days. While the trip itself takes a comfortable seven minutes, it may take two to three hours of waiting to get onto the ferry.

As mentioned, a bridge can affect the island's boundedness and reduce its remoteness simply by providing a more straightforward road, with fewer stops and fewer means of transport. Thereby it may also threaten to transform the magical (and expensive) island into an ordinary (and cheaper) place. To the islands of Muhu and Saaremaa, a 25-minute ferry trip from the Estonian mainland, around 1.5 million passengers travel annually (Visit Saaremaa, 2019). In a somewhat self-ironic mode, Saaremaa's tourist office points out that the feeling of remoteness is indeed strong on the island; there are no ferry or airplane services after sunset (Visit Saaremaa, 2019). The introduction of a bridge or tunnel has been discussed since the 1990s. The tourist agency staff believes that it is mostly a political game: before every election, the bridge is discussed in lively fashion, then it is quiet over the next four years (Interview 2011-02-11). An opinion poll from 2002 showed that 70\% of the mainland population and $85 \%$ of the islanders were in favour of a bridge. Negative voices meant that it would lead to increased crime and destroy the charm of the islands: a bridged island is no longer an island (The Baltic Times, 2002). They hardly need to worry: Estonian transport authorities have estimated that a bridge would take three years to build, but thirty years to pay off. 


\section{Distance in time and space: Allochronism}

To standard dictionaries, remoteness is first and foremost a matter of geographical distance. Such distance is important, but so is time, as is mentioned in the Swedish National Encyclopaedia: "that which is far away, in time or space" (n.d.). However, this 'or' could preferably be replaced by a conjoining 'and': a core of remoteness is distance in space and time in just the right proportions.

Allochronism is the anthropologist Johannes Fabian's term for the attitude whereby places and peoples are held at a distance by being placed in a different temporal plane, thereby defining a border between modern and old, civilised and primitive, 'high' and 'low' (Fabian, $1983 / 2002$, p. 32). The spatialisation of temporal, cultural, and social demarcations makes it possible to map them geographically in terms of proximity and distance, centre and periphery. Travelling to remote places thereby implies a distinct direction; the spatial movement away coincides with a movement backwards in time. While the 'here-and-now' is located in the centre, the 'there-and-then' is the given position of the remote. If the past is a foreign country, remote foreign countries are also in or of some past. From such countries it is possible to reach modern times in no time: "In one night, they travelled one hundred years into the future," the Swedish journalist reports in an interview with aged Assyrians from the Middle East now living in Södertälje, Sweden (Dagens Nyheter, 2005).

As micro-worlds of their own, islands are especially apt for allochronistic positioning. As island scholars have repeatedly noted, one of the most powerful components of the inclination to romanticise islands and island cultures "is the tendency to see islands not just as otherworldly, but other-timely" (Sparling, 2011, p. 50; Gillis, 2004, 2007; Lowenthal, 2007). Allochronism turns remote places into chronotopes positioned in a vague, indefinite past. For Bachtin (1981, p. 84), the chronotope- "the intrinsic connectedness of temporal and spatial relationships that are artistically expressed in literature" - is not just any artistic device that may or may not be employed. The chronotope is what constitutes and defines what we understand as genres, collectively established forms or types of communication "with sociallyagreed upon conventions developed over time" (Bachtin, 1981, p. 84; “Genre”, n.d.). When time and space converge, the hard facts of remote and islanded places easily turn into a genre of fiction: a chronotope of living archives and repositories, perfect places for studying past civilisations and phases of development that modern places have left behind. "Just like Sweden in the 60s," Swedish travellers often described their impression of the Estonian island Saaremaa following the collapse of the Soviet Union. Also, islanders of nearby Åland tell of the habit of Swedish visitors to compare contemporary life in Åland to their childhoods' Sweden (Ronström, 2016).

Cape Breton Island, in the Canadian province of Nova Scotia, has long been idealised as the place where Scotland's Gaelic heritage has survived. Here in 'New Scotland', it is said, not only the Gaelic language has been preserved, but also traditional folkways, songs, dance, and music that disappeared in Scotland in the 19th century. The island "is not simply imagined as a Scottish place in Canada, but rather as a place from Scotland's past," writes ethnomusicologist Heather Sparling (2011, p. 51, emphasis in original). With such a position follows a certain responsibility: in centres like Edinburgh and Glasgow, styles and fashions, and ways of speaking, thinking, and living, may come and go without much concern. But this occurs, anthropologist Malcolm Chapman (1992, p. 97) argues, in light of the fact that 
there are remote areas ascribed with a moral responsibility to preserve tradition, language, and heritage. As an island at the remotest fringe of the Gaelic periphery, Cape Breton becomes responsible for preserving a Scottish music, dance, language, and culture long lost in Scotland.

One of the island's major attractions is the Cabot Trail, a trip along the coast of the island that circles its geographical and cultural distinctiveness for tourists and islanders. At the one end is a malt whisky distillery, the only one in Canada; at the other the equally unique Gaelic College of Celtic Arts and Crafts. In between, you pass through the island's 'highlands', small villages and a reconstruction of a typical Scottish sheep farm, before switching to the Ceilidh Trail, a chain of venues with live traditional dance and music. It is no coincidence that Cape Breton is staged more as a living reality than a museum: the island "isn't simply a place where the past was, but where the past still is" (Sparling, 2011, pp. 53-54, emphasis in original). It is also no coincidence that excellent folk musicians and dancers are among the island's export products, nor that tourist attractions with a focus on modernities are hard to find. Even in the museums commemorating the activities on the island of two of the heroes of modern technology, Alexander Graham Bell and Guglielmo Marconi, the past is in focus (Sparling, 2011).

Allochronism is a perspective that positions modernity and development in the urban centres of nations and continents. There, time seems to move forward at an increasingly rapid pace. In remote places, time seems to move slower and is measured against different scales. A tourist brochure from Estonian Saaremaa speaks it out in plain language: "Everything begins here and everything ends here. Even time moves at a different pace; on the island of Muhu, it doesn't move at all!" (Visit Saaremaa, 2019). In such places, you may find links to the past, lost childhoods, and good old days. As the Cape Breton example demonstrates, allochronism can serve as a strategy for the symbolic reproduction of the stable, immovable, and continuous in a world increasingly marked by change and mobility. The idea of a slower island time is nurtured by experiences of increasing whirls of time on the mainland. The idea of an acceleration of time in the growing continental cities is energised by images of a slower pace of life in islands (Gillis, 2004; Lowenthal, 2007).

\section{Remnants of Golden Ages}

Allochronism is amplified by remnants of bygone golden ages, of which there can be many in remote islands. Ruins of forts and castles, old churches, and mansions that in mainland centres may stand as proof of development's inexorable march into the future, may in remote places be regarded as proof of abandonment, stagnation, and pastness. In remote islands, such remnants typically stand as silent calls for a saviour and precisely the kind of progress that the islands once fell victims to (Ardener, 1987, p. 45; Ronström, 2016, p. 154). In recent decades, much have been conserved, heritagised, and used to promote islands as tourist destinations: islands make up less than $1.5 \%$ of the earth's surface, but harbour around an eighth of UNESCO world heritages (Baldacchino, 2004, 2007b).

In Gotland, history runs especially deep. Few places in Northern Europe have exerted such attraction on historians and archaeologists. Since the early 19th century, Gotland has been ascribed so many different pasts, from antiquities, history, and tradition to heritage and world heritage, that Gotland's story is best written as meta-history (Edquist \& Holmén, 2015; Ronström, 2003, 2008a,b). Over the last few decades, there has been an intensive production 
of new kinds of past for new markets. Especially present nowadays is the Middle Ages, based on the striking physical remains of the 1100 and 1200s, and the popularity of present-day stagings like Medieval Week and the World Heritage 'Hanseatic Town of Visby' (Gustafsson, 2002). But it is also, and perhaps more importantly, an outcome of the productivity of two centuries of historians focusing almost solely on the island's Middle Ages. Like Cape Breton Island, Gotland has been actively and purposefully produced as a living museum, a place where the past still is (Edquist \& Holmén, 2015; Holmén, 2014).

In the 1960s, young Gotlanders like myself were taught to treat Visby's medieval ruins and city wall with respect and pride. What had to us been exciting sceneries for play and adventure was to be transformed into symbols of a golden age of wealth and power: back then, in the 12th century, Visby was by far the richest place in Northern Europe, a wellconnected town of prosperity and progress filled with merchants and travelers from afar. But what the history lessons also taught us was that Gotland of our own time was remote, isolated, and poor, and that the only road to education, jobs, and a more prosperous future led to the growing urban centres in the mainland. The many remnants of past heydays showed us a Janus face: on the one hand, a standing call for pride of what medieval Gotlanders had accomplished and, on the other, a constant reminder of decay and the shortcomings of all later generations of islanders, not least my own (Ronström, 2008a,b; cf. Anderson, 1983/2006, p. 172).

\section{Isolation and connection}

Isolation is commonly seen as an inevitable companion of islands. This has not always been the case. Even though 'isolation' and 'island' have the same linguistic root, islands were not necessarily seen as isolated or remote until the last two to three centuries (Gillis, 2004, p. 113). A telling example is the worldviews of the first Scandinavians to "go west" into unknown and uncharted territories in the 8th and 9th centuries. The medieval Landnámabók, the story of how Iceland was first found and settled, provides a detailed itinerary over the North Atlantic world around the year 1000. It took the settlers seven days to sail back to Norway, five days to Ireland, four days to Svalbard, and, from Kolbeinsey, in north Iceland, only one day to the "wild, uninhabited regions of Greenland" (Heiniger, 2017, p. 61). As Anna Katharina Heiniger (2017) points out, this suggests that the first settlers found themselves well connected to a wide network of communication and trade in the North Atlantic world. There certainly were distances; some places might even have been deemed 'afar'. But of isolation, remoteness, or islandness there are few traces. That Iceland is an island is mentioned only once in the old Icelandic texts, and of no further importance or consequence for the settlers (Heiniger, 2017, p. 61).

Etymology Online (2019) gives clues to the changes island-related words have undergone during the last centuries. 'Insular' ("of or pertaining to an island") enters English in 1611 as a descriptive term, without negative connotations. This was during a time when the English began to perceive themselves as islanders. Insular nations, among which the British saw themselves as the foremost, were then portrayed as the freest, most cosmopolitan, and progressive in the world. In the poetry of the time, 'the island' became a trope of connection, belonging, and community. The growing trade, the archipelagic, and the Britannic merged into a tribute to an empire characterised by peace, prosperity, and freedom. Now the goddess 
of liberty settled in Britain to become an island-Goddess, "whose influence bound together the scattered islands of the growing British Empire" (Edmond \& Smith, 2003, p. 15; Ellis, 2003).

It is not until the second half of the 18th century that 'island' becomes a metaphor for isolation and alienation. 'Isolated', a rendering of French 'isolé', appears in English in 1740, for 'separated' or 'detached'. In the following decades, 'insularity' and 'insular' take on new meanings, as 'introverted' and 'narrow-minded'. 'Insulate', a word introduced in a descriptive sense already in the 17th century ("to make into an island"; Etymonline, 2019) now acquires more figurative and negative meanings, as in "block" or "detached from surroundings [1785;" Etymonline, 2019]). Swedish 'insulär' appears to have changed during the 19th century, from descriptive usages ('alone', 'independent') to more negative and metaphorical usages ('separated', 'secluded', 'off') (Hellquist, 1939/1980). Similar changes can be found in other European languages, related to the 'continental turn' in the late 18th century, which positioned the islands of the Atlantic world in the peripheries and the continents in the centres. When the emerging continental world turned its backs to oceans, seas, and lakes, water acquired new meaning, now more of a barrier than a carrier (Gillis, 2004, p. 124).

\section{The illusion of isolation}

Like remoteness, isolation is a matter of distance, connection, and perspective. In principle, isolated places can be found anywhere; in mountains, deep valleys, jungles, glaciers, steppes or prairies, deserts, borderlands, war zones: all kinds of places positioned in the fringes of civilisation or beyond, places to which few or no roads lead (Ardener, 1987, p. 41; Tuan, 1980). Among isolated places, islands occupy a special and privileged position by being surrounded by water. As Gillis reminds us, such positioning comes with a certain perspective: although for the landlubber water may create "the delicious illusion of isolation," for the islander it "has been no barrier to exodus" (Gillis, 2001, p. 54).

In the human world, water has long been especially effective to delimit, separate, and encompass, and to have cultural differences and borders perform as natural. Water is a natural(ised) point of reference for many of our most basic categories, such as beginning and end, here and there, connection and separation. The experience of movement in and over water shapes our ways of perceiving weight, height, volume, density, speed, proximity, and distance. For geographical and political boundary work, water is central: borders between continents, nations, regions, and counties are commonly drawn in seas and lakes, along rivers and coastlines.

But to island a place or phenomenon, water is not necessary. All islands are not surrounded by water; nor are all places surrounded by water islanded. Even if totally surrounded by water, some places resist islanding by being large, central, or important. Conversely, smaller and less important places are more easily islanded also if they have no connection to water. Typical of islanded objects - the oasis, the kitchen island, the traffic island, etc. — are protruded and/or elevated seclusion. This is precisely what water is especially good at: to set off pieces of land as naturally secluded, detached, and isolated. The notion of a natural seclusion activates a search for boundaries. The emphasis on the boundary between water and land as natural, constitutive, and definitive leads to ideas of a particular boundedness. This reinforces two common ideas: islands as complete 'worlds' of their own, and islands as isolated and insular. The emphasis on the relation to a mainland gives way to an image of islands and continents as each other's first or main 'other' in absolute terms: the 
one large, the other small, which in turn tends to reinforce another common set of ideas: islands as vulnerable, insidious, dependent, and problematic. The mainland/island duality is thus structured not only by water, size, and position, but also by a number of other underlying value hierarchies: proximity/distance, independence/dependence, adequacy/inadequacy, completeness/lack, etc. (Gibson-Graham, 1998; Stratford et al., 2011). An island is, Baldacchino (2005, p. 248) writes, "a nervous duality" that "confronts us as a juxtaposition and confluence of the understanding of local and global realities, of interior and exterior references of meaning, of having roots at home while also deploying routes away from home."

A nervous duality indeed: everywhere dualities, dichotomies. As geographical entities, and as ideas, metaphors, and images, islands are made of dualities. But, however 'natural' they may seem, just as any map, they are not models of but models for the world.

\section{Isolation: Threat and promise}

On islands without regular scheduled service connections, there is a constant threat of sudden isolation in the background. "You can't just jump into the car and leave" is a common remark in interviews about the disadvantages of island life. Today, the mere threat of becoming isolated and disconnected is potentially stressful, as when the batteries in the mobile phone are completely discharged or the internet is unavailable. In the same way as connection has become a master metaphor for modern, updated, and in the centre of the action, isolation and disconnection has become a master metaphor for backwardness, social death, and marginality.

An essential part of the symbolic power of the deserted island is the threat of becoming abandoned and left alone with yourself. The bottled messages and other flotsam that cartoonists have floating ashore on deserted islands serve only to underline the fundamental isolation (Kinane, 2011; Ronström, 2016). The Robinsons alone on their deserted islands, just like the astronaut in a lost spaceship or the patient with advanced dementia or Alzheimer's disease, are incarnations of the ancient horror of being buried alive. What is most frightening is not the physical solitude, but the social death that comes with the inability to communicate.

Temporarily and chosen by free will, isolation can be positive. To break up, to abandon everyday routines and habits, is one of modernity's strongest key scenarios. Such break-ups are often associated with old and well-rehearsed religious practices: the hermit, the spiritual searcher, all alone with God and yourself. 'Retreat' is one of the results: the idea of voluntary, physical isolation and social and technical disconnection, to give room for spiritual connection. Today, many travel to islands and other islanded places not only for relaxation, but also to 'find oneself and connect with other ways of being. Beaches, the liminal zone between land, sea, and sky, especially exert strong attraction on those seeking space for contemplation and transcendence (Dening, 2004; Gillis, 2012). And, since islands consist largely of beaches, this has become an increasing part of their magic.

\section{Connectivity}

Anthropologist Edwin Ardener argues that a sign of successfully established remoteness is a special engagement in connectivity. In big cities, the street where you live will take you to the next street, and then to the next and next again, before you even get anywhere. But in remote places, the street where you live can take you straight into the big, wide world: 
Remote areas are obsessed with communications, the one road, the one ferry, the tarring of the road, the improvement of the boat; the airstrip on reclaimed ground or even on the sandy beach. The world always beckons - the Johnsonian road to England, or the coast, or wherever it is, is an attraction to the young, for it leads from your door to everywhere. (Ardener, 1987, p. 46)

Among Gotlanders, such an engagement in connectivity is easily notable. The quality of ferry and airplane services is constantly discussed, as are timetables and prices. The supply of electricity and phone connections are other issues of constant complaint around the island. Around the millennium shift, internet connections, broadband, and bandwidth also became common topics of conversation. From 2010, a 'fibre fever' swept the island, when the regional administration decided that all households were to be connected with fibre internet. While the inhabitants of Visby were at first reluctant to engage in the project, people in rural areas with weak or no internet connection immediately stood up to be the first to acquire the new fibre technology. In 2016, the project's goals were reached. Today Gotland is one of the best digitally connected parts of one of the world's best digitally connected nations.

Did Gotland thereby become less islanded, less remote? In the eyes of the islanders, definitely. But not necessarily to outsiders. In the same period the marketing of Gotland as an island destination boomed, focusing on Gotland's illustrious pasts, its authentic language and traditions, its different feel ('almost abroad'), and pleasant climate. In 2007, a new brand for Gotland was created. After two years of work, the destination developers found that Gotland was already one of Sweden's strongest place brands, composed of associative words such as 'island', 'Fårö', 'Ingemar Bergman', 'summer', 'sun \& bath', 'beautiful', 'nature', 'city wall', 'medieval week', 'Pippi Longstocking', and 'the Baltic Sea'. The new brand 'Magic Gotland' was built on five core values: closeness, vitality, life-cycle, magic, and creativity, and a brand vision: "Gotland is the Baltic Sea region's most creative and magical place, characterised by proximity, sustainable growth and filled with joie de vivre" (Guteinfo, 2018).

This discourse clearly belongs to a generic island speech, a uniform, globalised genre that seems to hover rather freely over the island it is supposed to refer to. Through a number of rhetorical figures and techniques, such as aesthetics, homogenisation, idealisation, and distancing, a fundamental difference is established between an observing active subject and an observed passive object (Spurr, 1993). The islands' remoteness and boundedness pave the way for notions of archaism-conservatism, old age, backwardness-and endemism-isolation, inbreeding, and narrowmindedness. Such notions form a packet of two different but closely associated moods. The one positive, emphasising proximity, warmth, and context; the other negative, emphasising isolation, inbreeding, and stagnation. Together, they form a potent affective image, which at the same time is an effective contrast image in which the island appears as what it is not: continental, developed, and modern.

The degree of remoteness bears a clear relation to the degree of connectivity with the surroundings and how this connectivity is perceived. Where the big central systems, such as the state and the markets, are unable to fully reach their targets, a feeling of being set aside or standing apart can easily emerge. Such places can be found anywhere, but are especially common in border areas, outskirts, fringes, slums, and on islands where the "hard edges of social order at the centre become blurred as their lines extend outwards into distant and 
difficult terrain" (Harms \& Hussein, 2014, p. 367). Such places are not positioned 'outside society', as is sometimes argued in political rhetoric; instead they are connected in special ways. Thus, remoteness and peripherality is not synonymous: all peripheral places are not remote, nor are all remote places peripheral (Albert \& Vasilache, 2017). Large, faraway places may become centres in their own right. Baldacchino (2020) finds that an island's development agenda is significantly determined by the effects of distance from the locus of its central government. While "physical remoteness suggests that a subnational island unit has more jurisdictional autonomy [...] to determine its own future" (Baldacchino, 2020, p. 26), closeness to the heartland reduces the islands 'room for manoeuvre'. "Thus: how far one can go-in terms of a specific island-driven development agenda - may really have something to do with how far one is" (Baldacchino, 2020, p. 2).

"The lesson of "remote areas'," Ardener (1987, p. 50) concludes, "is that this is a condition not related to periphery, but to the fact that certain peripheries are by definition not properly linked to the dominant zone." When properly linked, faraway places may not appear as remote, especially if they are perceived as large or important. But when remoteness becomes a defining characteristic of a place or object, it can become difficult to get rid of, especially for smaller and less important places at a border, fringe, edge, or in a dead end. A telling example is Svalbard's Longyearbyen, the world's northernmost settlement. A former mining town of around 2,000 inhabitants, Longyearbyen has long been reputed as one of the world's most remote and isolated places. However, after the decline of the mining industry in the 1990s, the town developed into a well-connected research hub and tourist destination. Daily flights bring in more than 80,000 passengers yearly, in addition to the 30,000-40,000 passengers on the approximately 30 large cruise ships that arrive during summer, attracted and fascinated by the exotic appeal of isolation and remoteness. As a result, the number of guest nights in Longyearbyen has increased from around 50,000 in 1996 to more than 130,000 in 2015 (Statistics Norway, 2016). Will Longyearbyen thereby become less remote? Perhaps, but not necessarily. Regular flights and ferry service, telephone, and internet may bring in large numbers of visitors and provide efficient high-speed connection, but linking places like Longyearbyen properly to their dominant zones might not be enough to un-remote them.

\section{Movements and transports}

Remoteness is produced, not discovered - a result of projecting ideas about human relations, social development, and the progress of time upon physical geography. It is a volatile mode constituted by absence rather than presence, requiring both distance and estrangement, in time and space. You cannot easily settle down in remote places. If you stay too long, the qualities of remoteness will fade away. The remote is not an end station, Gillis notes (2001, 2004), for just like the feeling of homeliness, it arises from cyclical movements back and forth. The remote is thus somewhere where you have to travel. Without returning home to the 'here and now' of everyday life, the journey to remote places 'there and then' would not be possible (Gillis, 2001, 2004).

Remoteness is produced, Gillis argues, by certain kinds of movements, travels to places that are neither too close, nor too far away. More than distances, remote places depend on how difficult they are to reach. Today remote places may be located not very far from large cities, whilst faraway places may be within close reach. Relative inaccessibility is a 
characteristic: a remote place must be possible to reach, but it must not be too easy. A certain level of difficulty and a certain amount of time are required. While roadlessness produces heavy-duty remoteness, quick, effortless transport, straight paths without stops and breaks, destroy the feeling of remoteness:

Starting, stopping, and waiting are all part of the construction of remoteness. Getting there must be something of an adventure, a test, amounting often to a trial, that transports the traveller mentally as well as physically. (Gillis, 2001, p. 47)

The more stops, transfers, and the more means of transport that are used, the more adventurous the journey and the more remote the destination. The more and the longer you have to wait, whether due to airplane or ferry departures, border control, customs, or bad weather, the more remote the experience. Taken together, the arrivals, departures, and all the repetitive, ritualised actions required by the journey add to a sense of remoteness.

In modern, urban environments, there is not much space for the remote, Gillis (2001) notes. Borderlands of different types, especially islands, have become the favourite places of remoteness because they are sufficiently inaccessible and thus tempt us to the ritualised behaviours and spatial practices that create the feeling of remoteness. "Islands have become the contemporary world's most favourite location for remoteness not so much because of the distances involved as because they facilitate the cultural practices that constitute it" (Gillis, 2001, p. 47). Whilst the uninterrupted travel from A to B contributes to a sense of closeness and accessibility, the bridge, ferry, or aeroplane to and from the island marks disruptions and borders and contributes to the feeling of remoteness. All the arrivals and departures emphasise interruption and temporality, as do the visitors, whose experiences soon are transformed into recollections of the different and remote.

\section{Three hours away}

Commercial carriers conclude that three hours is how long people of today can manage to travel before they start to get impatient. Today, a 'Three Hour Rule' is firmly integrated in the timetables of Europe's high-speed trains and charter flights. To the travel industry, beyond this is where remoteness starts.

Just over three hours is what it takes modern high-speed ferries to reach Gotland. A visitors' guide emphasises that "Gotland is admittedly an island, but that does not mean it is difficult to reach" (Gotland.net, 2018a). The ferry company adds: "Gotland—a short trip far away!" (Gotland.net, 2018b). "Half a day away. Visit the islands characterised by calmness and freedom," announces Visit Åland, Åland's tourist organisation (2018). "You may think that Shetland looks remote on the map-we're 600 miles north of London, as far away as Milan or Berlin—but the islands are surprisingly accessible," the Shetland tourism agency claims (Shetland Islands Council, 2018), a message that the tourist agency in the Faeroe Islands also emphasise: "Despite the remoteness, you will find the islands surprisingly accessible" (Visit Faroe Islands, 2018; cf. Malm, 2013, p. 72).

Notable here is the special engagement in connectivity that Ardener points to. "Nearer than you think" is a message about a place supposedly at a distance, perhaps even remote. The departure point is the modern metropolis. It is to urban travellers this double-tongued 
message of the travel companies is directed: Travel with us to remote places! It is nearer than you think! It emphasises closeness and accessibility while at the same time producing distance and remoteness; and perhaps, more importantly, the centrality of the potential customer.

\section{The temptation of the remote}

Dreaming of islands - whether of joy or fear [...] - is dreaming of pulling away, of being already separate, far from any continent, of being lost and alone-or it is dreaming of starting from scratch, recreating, beginning anew. (Deleuze, 2004, p. 10)

Modern communications have made all parts of the world more accessible than ever. With less impact of physical distance, more and more people turn to bygone times to regain a feeling of remoteness, be it the Middle Ages, the Viking Age, the 18th century, or some fantasy past. Today it is not uncommon to feel more at home in places you have never visited and in pasts you have never experienced. It is a feeling nourished by knowing enough - but not too much - about these places and pasts. It becomes all the more valuable by remaining safe from the entropy of ordinary life. This, Gillis argues, may help to explain why the dream about the small, remote, or undiscovered place has become so powerful in an era when nothing is really physically inaccessible: "Today our most significant places are not those we dwell in physically but those we dwell on mentally. They are not physical locations, but cultural constructions, often kept at a distance" (Gillis, 2004, p. 147, emphasis in original).

As remote places become increasingly scarce, remoteness becomes increasingly desirable. Increased demand and expanding shortages make remote places more exclusive and costly. If remote places in a geographical sense today are hard to find, they could just as well be produced anywhere. By relating to time and space in certain ways and by assuming the necessary affective mode, we can produce what we can no longer so easily find (Gillis, 2001, p. 39).

As mentioned, remoteness is a fragile and volatile quality. To maintain the image of a time or place as remote requires a continuously active neglect of significant parts of the present in favour of something absent. It is an ability that is not given but achieved by consequent training. If the right feeling of temporal and spatial distance does not appear, for example because the objects and qualities that support the feeling of remoteness or nostalgia are too scattered, a solution is always to simply increase the density by creating destinations where the ordinary contemporary outside world is made invisible and modern fantasy is given full freedom (Gillis, 2001, 2004; Ronström, 2008b).

\section{Islanded islands}

Among such fantastic places, islands are abundant. The number of nesophiles, islomanes, and islomaniacs is rapidly growing. What many of them seek is remoteness, a sum of spatial and temporal distance that will produce differences that make a difference, which often means in contrast to the lifeworlds of mainland urban centres. On the Swedish west coast, in the vast archipelagos of the Baltic Sea, in the Caribbean, we see the result: 'islands of the mind'totally islanded islands, transformed to better fit late-modern dreams of the perfect place, far from the stress and press of modern urban life. The most extreme among such literally fantastic 
places are perhaps the six artificial islands just offshore Dubai fashioned to depict palms, the Earth, and the Milky Way, closely followed by the artificial Federation Island off the coast of Sochi in the Black Sea, shaped like the Russian Federation.

The tourist industry has long represented islands as temporally and spatially remote destinations. The otherness of tourist islands builds on a combination of remoteness and the necessary contrast to the known and near. Part of the temptation of these islands relies on the possibility to keep aspects of urban modernity at bay and present them as small-scale, serene, calm, unchanging, motionless, and quiet (Lindh \& Myte, 2009; Ronström, 2013; Salzman, 2007). But as the popularity of island-destination grows, their remoteness and otherness decreases, along with quite a bit of their calmness and serenity. This drives producers of exclusive destinations to even more remote places. At the island of Silverskär, just off the northern coast of the main Åland Island, visitors are offered a completely private island, here portrayed as an antipode to modern city life:

There are many things to see in Silverskär: the smooth, red granite cliffs, a forest nook where water lilies bloom in summer, the meadow with seven different flowers, and red buildings carefully renovated by gentle hands. Nature invites you to enjoy peace and quietness where each season has a special charm. Guests receive personal attention. Those reserving their stay at Silverskär, get the complete island at their disposal as only one group is accepted at a time. (Silverskär, 2019)

On the small island of Furillen off the northeast coast of Gotland, the owner of the exclusive hotel built in the remnants of an old limestone quarry expanded his enterprise with 'hermitages', small cabins going for Euro 250 per night. The journalist from the local newspaper reports:

Remove your watch and put it in the Watch Parking, then take off your silk tie. Leave mobiles and laptops behind. [...] Carefully located in the spectacular settings, the 7.8 square metre cabin is made of old farm boards. The cabin has a fireplace, a bed with a plush duvet and a small table with a single drinking glass. This is what you get, total seclusion and hopefully complete harmony. Your own neighbours are the local sheep, cows and three Gotland ponies. (Gotlands Tidningar, 2005; author's translation)

Today, those searching for remote, deserted islands need not search for long. There are so many islands out there, only a small number of them are inhabited, and in many of the inhabited ones the population is decreasing. Some are for sale or rent. Private Islands, one of many sites that provide the keen buyer a private island, lists some 900 objects, most of them small warm-water islands, all of them sufficiently isolated and remote (Privateislandsonline, 2019). Rich celebrities and politicians (Marlon Brando, Rod Stewart, Mussolini, Tito, just to name a few) may thus have their own islands, only inhabited by themselves and their servants. But the less resourceful also have a large selection to choose from. The travel agency Docastaway helps those inclined to find the right deserted island. According to the company's website, the staff has spent years exploring the most uninhabited and isolated tropical islands, those with still uncovered secrets, completely untouched by the influence of Western 
civilisation. You select the destination depending on the desired degree of isolation, from High to Very High.

Due to the perfect seclusion of these unspoilt desert islands you will feel like a castaway, and yet still enjoy the comforts of a relaxing beach holiday. [...] We have meticulously selected those deserted islands with the most secluded pristine beaches in the most beautiful archipelagos around the world [...] those places where time ceases to exist. These are places in which to escape from reality and lose yourself in nature's perfect creations. Welcome to the world's last paradises. (Docastaway, 2016)

If you are looking for true adventure, you can be completely on your own. However, you can also settle for the Comfort option, which includes a comfortable accommodation with electricity, running water, internet access, and exclusively prepared meals. A tempting offer for the modern Robinson.

\section{Nostalgia}

"Remoteness is to space what nostalgia is to time," Gillis suggests (2001, p .55). While modern nostalgia emphasises distances in time, remoteness underlines spatial distances. So it may seem, but there is more to it: nostalgia was always also a lot about space, and remoteness a lot about time. In 1688, when nostalgia was born as a medical diagnosis, it was a "distance sickness," described by the young Swiss doctor Johannes Hofer as "the pain the sick feels because he is not in his home country, or fear never to see it again" (1688, as cited in Johannisson, 2001, p. 16). By the end of the 17th century, nostalgia had become a significant bodily disease, very lethal, caused by strong home-longing. Any sensitive person could suffer from nostalgia, but most vulnerable were young people far away from home, students studying in foreign places, soldiers, and seamen, who in the late 1600 s did not only become more numerous but also traveled farther away and for longer periods of time than ever before. In her inspiring study of the history of nostalgia, Karin Johannisson (2001) shows that although the diagnosis changed over the centuries from longing for place, belonging, and proximity, to longing for nature, self-identity, and times past, the core remains the same: the experience that "sudden change, relocation, or marked discontinuity in life meant a crisis for the self" (Johannisson, 2001, p. 78; cf. Gillis, 2003, p. 25).

It is at the end of the 19th century, a time of increasing, large-scale changes, relocations, and discontinuities, that nostalgia finally disappears as a medical diagnosis. When the measure of modern society had become to what extent it left the past behind, nostalgia's object changed from lethal home-longing to a pleasurable and harmless, melancholic, and bittersweet yearning for bygone days, "a languishing and self-conscious longing, a grief without object" (Johannisson, 2001, p. 11). For the Swiss soldiers diagnosed as nostalgic in the 17th and 18th centuries, the only cure available was to return home. For modern nostalgia, however, there is no cure. In relation to modernity's 'Four Great'-Reason, Renewal, Change, and Movement - nostalgia becomes normalised as a low feeling, contemptible and condemnable in its looking backward, a disgraceful shortcoming, and a symptom of an inability to be modern (Johannisson, 2001). The object that modern nostalgia embraces is the past, but it is a past that can be visited in the present, most notably in faraway, remote places. Although 
embraced, the past is at the same time held at arm's length: "Nostalgia constitutes what it can not possess and defines itself by its inability to approach its subject, a paradox that is the essence of nostalgia's melancholia” (Fritzsche, 2001, as cited in Gillis, 2004, p. 122).

Johannisson notes that when the 'good life' is linked to the past, nostalgia becomes utopian, together with nostalgia's favoured places (Davis, 1979, p. 49; Johannisson, 2001, p. 148). This is an important insight, because it shifts the perspective of modern nostalgia from lack, loss, and escape into a form of modernity criticism. Modern nostalgia, Johannisson (2001, p.159). concludes, is characterised by self-seeking "based on key concepts such as ambiguity, revoked time layers, emotion and the return of the subject." In essence, it is a romance with distance, which means that "memory (recollection) and expectation (imagination) can enhance reality, transform, remake and enrich it. Both collaborate with imagination and can only be applied to the past or the absent" (Johannisson, 2001, p. 159). Thus, modern nostalgia is characterised not by painful homesickness, parent longing, or fear for the new, but by selfseeking and a retained subjective time within a larger feeling of rushing time:

Its triumph is that it allows individuals to long and fantasise over the own self in a stream of images, experiences, bodily recollections, feelings, moods, associations and vague reminiscences to establish contact with their own life histories. (Johannisson, 2001, p. 159)

Clearly, remoteness is in several ways related to nostalgia. Both emerge in a rapidly expanding world, with new and broader dimensions and new emotional experiences: a world in which longing becomes central. Both are doubly charged perspectives and affective modes, at the same time attracting and repelling. In both the essence of the attraction is a romance with distance/absence based on recollection, expectation, and imagination; a romance that "defines itself by its inability to approach its subject" (Gillis 2004, p. 122). When linked to a 'good life', both become utopian, together with their favourite places. And, lastly, while longing, lack, loss, and escape are central to both nostalgia and remoteness, both can also appear as forms of modernity criticism, when the affective interest in remote places or times past turns into a curious investigation of alternative ways of being and living (Gustafsson, 2002; Ronström, 2008b).

As much as nostalgia is a romance with distance, it is a distance not only to an imagined past, but also to faraway places. Not least it is a productive distance also to present life conditions and world views. It is precisely this distance that can produce new and alternative perspectives, aesthetic values, experiences, affects, and emotions that may, as Johannisson puts it, "raise reality, transform, remake and enrich it" by allowing individuals to "fantasise over the own self" and "establish contact with their own life histories" (Johannison 2001: 159, Ronström 2019, p. 13). This "utopian" aspect of nostalgia's romance with distance may well be an answer to why people like Judith Schalansky are drawn to remote places, since it may provide them with glimpses of alternatives, and to sense, feel, imagine, and identify with other forms of living and being (Kapchan, 2014. p. 18). And, as in the case of Schalansky, such glimpses of something other could then become a kind of beacon, showing the way towards a new and different future. 


\section{A geography of time}

The starting point for modern remoteness and Fabian's "allochronism" is the Age of Enlightenment and the emergence of modernity in the 17th and 18th centuries. Its prerequisite is a new temporal perception that imposed a direction on time and introduced an insurmountable gap between the past and the present. According to the French historian Pierre Nora (1989), what characterises the relation to the past in former times is the assumption that the past is possible to retrieve: "The past could always be resuscitated by an effort of rememoration; indeed, the present itself became a sort of recycled, up-dated past, realised as the present through such welding and anchoring" (Nora, 1989, p. 16; cf. Gillis, 2003 , p. 21). In the pre-modern world, there was no fundamental difference between past and present. What happened before remains in the past but is still accessible in the present.

From the end of the 18th century, the perception of time underwent a radical change from "a continuous, sacred Biblical time to an essentially discontinuous and fragmentary, naturalised and secularised, sequential and evolutionary time" (Fabian, 1983/2002, p. 12). The achievements of geology, archaeology, and philology during the early 19th century, and not least the growing interest in ancient and exotic 'antiquities' and folklore, made obvious that time had a direction and that this direction implied a certain morality: "The linear perception of time, accompanied by the belief in progress and development, contains the seeds for completely new narratives," writes the Norwegian folklorist Anne Eriksen (1995, p. 41; author's translation):

narratives about the passage of time, how time passes not only from one point to another, but from one state that evolves into another. The belief in progress is one of modernity's 'grand narratives', not only in a metaphorical sense; in itself it leads to a figure of thought that literally begs to be translated to a narrative about a beginning, a change [...] and an end. The story also has a moral: 'Progress wins and progress is good'.

It is when the past is separated from the present that 'history' emerges, or, with Nora's words (1989, p. 16), when the past is no longer a "retrospective continuity, but the illumination of discontinuity." When time evolves forwards, history becomes a distant, foreign country that can be attributed to distinctive qualities. The radical association of space with time, a cornerstone of European modernity, gives remoteness its new, modern meaning as an expression of a hierarchical, unequal, and asymmetric relation between phenomena or places.

\section{Survivals}

Anthropology, ethnology, and folkloristics are among the disciplines established in the second half of the $19^{\text {th }}$ Century that were "predicated on the transformation of time from secular time to naturalised time" (Fabian, 1983/2002, p. 9). The modern perceptions of time placed ethnographers and anthropologists in a privileged time here and now, while the researched 'savages', 'primitives', and 'tribes' were placed not only far away, but also in an earlier, less developed stage of evolution. This radical denial of coevalness, this "diachronic relegation of 
the Other" that Fabian (1983/2002, p. 37) terms 'allochronism', is a device that "at once constitutes and demotes its objects through their temporal relegation."

During the second half of the $19^{\text {th }}$ Century, a new world of spatialised time and temporalised space gained power, proliferation, and legitimacy. Darwin's studies of finches on the Galápagos Islands played an especially crucial role by attracting biologists, geographers, linguists, and anthropologists to studies of survivals and endemism in remote and islanded places. Soon, evolutionism à la Darwin became the paradigm of the day in natural sciences, as well as in cultural and social sciences.

In his much-read Primitive culture (1871), a cornerstone of cultural anthropology, Edward B. Tylor introduced ideas on cultural evolution and survivals that soon gained significance for the views on the origin of humankind, the difference between civilised and primitive, and how such differences can be mapped in terms of geography. Worth noting is that the empirical findings to support both Darwin and Tylor's theories had been brought from the same kinds of environments. Distant islands became favourite objects for speculations about evolution and progress. Their supposed remoteness, isolation, and boundedness paved the way for ideas about a natural endemism, as well as ideas about a natural archaism.

The ideas and concepts presented in Primitive culture paved the way for a shift from older romantic, collecting attitudes to more scientific perspectives on folklore as documents of progress and the passage of time, a counterpart to the ancient artifacts that archaeologists dug out of cultural layers (Hodgen, 1931, p. 323). To Tylor and his followers, it became clear that with comparative methods it would be possible to determine the origin, age, and degree of civilisation of individual cultural elements as well as whole cultures. As Fabian (1983/2002, p. 16) notes, this "promoted a scheme in terms of which not only past cultures, but all living societies were irrevocably placed on a temporal slope, a stream of Time, some upstream, others downstream."

Survivals soon became indispensable Grand Theory in folklore studies all over Europe, at hand whenever it became desirable to explain the remnants of bygone days in modern societies. Through Wilhelm Mannhardt's and James Frazer's work in the 1870s and 1880s about faith and practice in agriculture and harvest, Tylor's ideas were further developed by the concept of relicts: cultural elements that survive in certain geographical areas, but previously had a wider spread. Through spatial comparisons, researchers were now able to answer temporal questions. The notion of 'relict area' contributed to give the idea an even clearer design. Based on the notion that the least developed is the oldest, researchers took off to remote provinces in search of the origins of artefacts, rituals, practices, and beliefs.

Evolution and progress required new explanatory models. Combined, the concepts of 'survival' and 'relict' made it possible to perceive time spatially and space temporarily. It created an alloy of time and space that could easily and pedagogically be transformed into maps where centres became equated with modern development and periphery with stagnation and backwardness. Mapping became a standard method to answer questions about time, origins, age, and degree of civilisation.

Based on a number of rhetorical figures and techniques such as aesthetisation, homogenisation, idealisation, and distancing, modernity's temporal geography created a fundamental difference between an observing active subject and an observed passive object that made colonialism not only plausible and credible, but also indispensable (Fabian, 1983/2002; Ronström, 2008b; Spurr, 1993). Through such practices, remoteness gained 
significant explanatory power in modern society at large, not least as a legitimation of its centres and peripheries.

Fabian argues that it is not the dispersal of human cultures in space that led anthropologists to temporalise, but the other way around. It is:

naturalised-spatialised Time which gives meaning (in fact a variety of specific meanings) to the distribution of humanity in space. The history of our discipline /anthropology/ reveals that such use of Time almost invariably is made for the purpose of distancing those who are observed from the Time of the observer. (Fabian, 1983/2002, p. 25)

Fabian (1983/2002, p. 17) notes that "civilisation, evolution, development, acculturation, modernisation (and their cousins, industrialisation, urbanisation) are all terms whose conceptual content derives, in ways that can be specified, from evolutionary Time." Remoteness, I suggest, is yet one more of these terms, flowing, as it seems, 'naturally' out of the new evolutionary geography of time. Essentially, it is a concept of the mind rather than of the real world, a category to think with rather than an object for such thinking. And, as we have seen, it is a concept with many real enough consequences.

\section{Figures of thought: Remoteness and islandness}

Already in the second half of the 18th century, the 'continental turn' had made European islands increasingly peripheral. A century later, Darwin, Tylor, Frazer, Mannhardt, and others established a theoretical explanation to what had already become common belief: that islands are isolated relict areas, remote both in time and space. It is in this century, Gillis (2001, p. 40) notes, that islands "become, for better or worse, a prime location of remoteness, a reflection of global economic, political, and cultural processes that often seem beyond their control." These ideas soon became naturalised as a 'law of islands': insularity, a combination of boundedness, remoteness, and isolation, makes islanders handed to themselves; thereby they also develop their own distinctive cultures, more endemic and archaic than in the mainland, which in turn explains the large number of survivals on islands (cf. Cosgrove, 2007).

In terms of such a geosophy, the inherent ambivalences and conflicts in the modern project could be given spatial form. In the centre, an acceleration of time and history; in the peripheries, a corresponding retardation. In the growing mainland centres progress, modernity, and development; in islanded places the 'good old days', even utopias, an imagined past that adds contour and meaning to modernity but is accessible only through memory or deliberate reconstruction (Gillis, 2004; Johannison, 2001; Ronström, 2016). Today, islandness, remoteness, and pastness have become practically inseparable. Rather than a 'natural' intrinsic quality, remoteness is a consequence of a fundamental cultural asymmetry in a global archipelagic system (Depraetere, 2008a, b).

Tankefigur, 'figure of thought', is the social psychologist Johan Asplund's (1991) term for that which mediates between human action and discourse. When we write or speak about our experiences, we do so in shaped, moulded forms. It is the provisional shaping 'where reality is about to turn into a language' that is ensured by figures of thought; they are literally 'proto-types'. Figures of thought, Asplund (1991) argues, lie under or beneath rather than in 
language. Just like emotions, these figures can be found between the subjective experience, and the culturally and temporally bounded expression. They have form, which the word 'figure' implies, but they are mute. Figures of thought are relatives of 'perspectives'; they are a way of observing: "All observation is about observing something as something. Figures of thought and their functions are related to this 'as"” (Asplund, 1991, p. 15; author's translation).

Remoteness, I suggest, can be understood as a figure of thought, a perspective that has already acquired a certain form. When produced, it acquires a certain materiality that contributes to the organisation of the world in terms of time, space, economy, politics, and power. Islandness, following the same line of reasoning, can be understood as the sum of a potentially accessible and hierarchically arranged set of figures of thought with the ability to island places, phenomena, and objects. These figures of thought can be mixed and charged in different ways; the outcome is never predeterminate. Together, they establish directions, opportunities, an orientation towards islandness.

\section{Of fact and fiction}

Through many centuries, islands have been used as projection areas: paradises, utopias, dystopias, futurotopias, and retrotopias. Like all projections, the images of 'the island' mirror the ideas, needs, and realities of the projectors. John Connell (2003, p. 573) argues that islands are "places of discomfiting dialogues," in which social and spatial ideologies are constructed, landscapes and peoples reconfigured.

The need for harmonious alternatives to modern worlds, people and places controlled, coherent, comprehensible and manageable, has drawn dreamers and iconoclasts, adventurers and experimenters, those who sought both escape and control. [...] Even localised to generic always distant, Polynesian islands, the need for utopia has never been transcended and in a post-modern world placelessness almost requires islands of identity. (Connell, 2003, p. 573)

What islands offer, Connell (2003, p. 573) continues, is "distinct identities and spaces, an apparent combination of isolation and community, in an increasingly homogenous world." But it takes a certain distance in time and space to keep the spell.

'The island' is clearly a multirelational phenomenon, and so is remoteness - not least a relation between fact and fiction. The dictionary of imaginary places is a playful travel guide to fictional sites of world literature through several millennia: Shangri-la, Oz, Middle Earth and many more (Manguel \& Guadalupi, 2000). Over 1200 entries show the way to an outstanding rich and multifaceted universe. The reader will find places of all choices to visit; the perfect, without disturbing disorder, such as Atlantis and Utopia; the magical, where anything can happen; the beautiful and enchanting; the grotesque and awful. Not surprisingly, virtually all of them are islanded places with vague or no surroundings: cities, kingdoms, castles and countries. Nearly half are surrounded by water: islands and archipelagos, great places for the alternative, remarkable, and strange, the ordinary world turned upside-down. Minda, an island in the Mardi archipelago, is inhabited by sorcerers who for their charms use the fumes of minced human hearts, with the result that weak-stomached travellers are advised not to assist in the preparation (Melville, 1849). The island of the day before (Eco, 1995) got its name 
because it is impossible for visitors to fix a point in space from which time can be determined. Everything takes place in the past, therefore the island cannot be visited today. Visitors should be aware that they may not see the same as others, since the landscape mirrors every visitor's own experiences. Aeolia is a floating rock island surrounded by an indestructible bronze wall, home of the King of Winds (Homer, (900 B.C./1919). "Double Island", probably in the Indian Ocean, appears and disappears at will (Maspero, 1899), a fate that it shares with the island on which the cast in the TV series Lost find themselves stranded (ABC networks, 2004-2010).

In this rich encyclopaedia, it becomes evident what 'the island' offers human imagination: a well-defined microcosm, easily surveyable and controllable, with its own distinctive flora, fauna, and population. Whether portrayed as paradises, utopias, dystopias, hermitages, junctions, fragments, microcosms, laboratories, factories, or tourist destinations, these islands are variations on a theme, sharing a number of generic characteristics: homogeneity, boundedness, magical enchantment, distinctiveness, small scale, authenticity, archaism, endemism, isolation - and remoteness.

What also becomes evident is the difficulty to distinguish between literary and real islands. The authors' point of departure is that their book is not possible without reading fiction as facts, a reasonable idea without which literature would hardly be possible. What the book actually suggests is that it is the border between "fantasy" and "reality" that is fictitious. But then again, it is a border that comes with real consequences.

\section{Outro in exisle}

To end, an island, a map and a story. One of Schalansky's small chamber pieces in the middle of nowhere: In 1929 the dentist Friedrich Ritter and the teacher Dore Strauch step ashore on the small, remote, and virtually unpopulated island of Floreana, one of the Galapagos Islands in the Pacific, some 1000 kilometers east of mainland Ecuador. Both have left their home and spouses in Berlin to seek for themselves a place beyond law and civilisation. They build a hut in the crater of a dead volcano and retreat from the world. Clothes are worn only when visitors come. And they come plenty. First, the curious: paparazzi who want to sell the story of Adam and Eve of Galapagos to the world's newspapers. Then more drop-outs from civilisation: imitators and prying adventurers. In 1932, Eloise Wagner de Bousquet, a selfproclaimed Austrian baroness, arrives with cows, donkeys, hens, cement, and two lovers. She wants to build a luxury hotel on the island, but the grand plan soon dissolves into a simple tent. For a couple of years, she controls the islanders with whip and gun, terrorising animals and lovers. In 1934, she disappears without a trace. The skeleton of one of the lovers is found on the neighbouring island. Dentist Ritter dies of poisoned food. Only Dora returns to Berlin, while the world's newspapers wonder about what has happened (Schalansky, 2010, p. 92).

This story, a melodrama with unusual features, is an odd mix of fact and fiction. The events, the people, the places are all factual. But what attracts the couple from Berlin, the visitors, and the Austrian "baroness" and her entourage is fiction; fantastic stories about lonely remote islands, paradise, adventure, utopia, experiment, and hermitage. And, as always, whatever people take as real will have real consequences. The result is a story built from old, well tried-out motifs, images, and figures of thought, but unfolds in new and unexpected ways in an unusual place and with new actors. The bottom line? That remote islands are fantasy's darlings; favourite places for myths, dreams, and fantasies. High mountains, wild 
rapids, jungles, old and lost cities may have great appeal, but few earthly places offer as much space for imagination, facts, and fiction as remote islands. Again, it is the constant sliding between the physical places and the figures of thought we attach to them that make islands so attractive for our dreams and fantasies.

\section{Acknowledgements}

This paper is built on a conference presentation (Ronström, 2017). I am in debt to John Gillis and Godfrey Baldacchino for inspiration and support over several years, and to comments by Deborah Kapchan, Swaminathan Ramanathan, researchers of the Ethnology and Anthropology seminar at Uppsala University, and the anonymous reviewers.

\section{References}

ABC network. (2004-2010) Lost. TV-series.

Albert, M., \& Vasilache, A. (2017, January 15-19). Rethinking centre-periphery relations and remoteness: Combining cultural theory and theories of social differentiation [Conference presentation]. REMOTE: Rethinking Remoteness and Peripherality, Longyearbyen, Svalbard, Sweden.

Anderson, B. (2006). Imagined communities: reflections on the origin and spread of nationalism (3rd ed.). Verso. (Original work published in 1983)

Ardener, E. (1987). "Remote areas": some theoretical considerations. In A. Jackson (Ed.), Anthropology at home (pp. 38-54). Tavistock Publications.

Asplund, J. (1991). Essä om Gemeinschaft och Gesellschaft. Bokförlaget Korpen.

Bachtin, M. (1981). The dialogic imagination. University of Texas Press.

Baldacchino, G. (2020). How far can one go? How distance matters in island development. Island Studies Journal, 15(1), 25-42. https://doi.org/10.24043/isj.70

Baldacchino, G. (2007a). Bridges \& islands: A strained relationship. In G. Baldacchino (Ed.), Bridging islands: The impact of fixed links (pp. 1-14). Acorn Press.

Baldacchino, G. (Ed.). (2007b). Bridging islands: The impact of fixed links. Acorn Press.

Baldacchino, G. (2005). Islands: Objects of representation. Geografiska Annaler, 87(4), 247251. https://doi.org/10.1111/j.0435-3684.2005.00196.x

Baldacchino, G. (2004). The coming of age of island studies. Tijdschrift voor Economische en Sociale Geographie, 95(3), 272-283. https://doi.org/10.1111/j.1467-9663.2004.00307.x

The Baltic Times. (2002, July 11). Saaremaa Islanders Want Bridge. The Baltic Times. https://www.baltictimes.com/news/articles/6632/

Chapman, M. (1992). The Celts: The construction of a myth. St Martin's Press.

Connell, J. (2003). Island dreaming: the contemplation of Polynesian paradise. Journal of Historical Geography, 29(4), 554-581. https://doi.org/10.1006/jhge.2002.0461

Cosgrove, D. (2007). Island passages. In G. Baldacchino (Ed.), Bridging islands: The impact of fixed links (pp. 15-27). Acorn Press.

Dagens Nyheter. (2005, September 22). Nyhetsdygnet. Fredag 2 September 2005. Dagens

Nyheter. https://www.dn.se/nyhetsdygnet/2005-09-02/

Davis, F. (1979). Yearning for yesterday: a sociology of nostalgia. Free Press.

Deleuze, G. (2004). Desert islands and other texts, 1953-1974. MIT Press. 
Dening, G. (2004). Beach crossings: Voyaging across times, cultures and self. Melbourne University Press.

Depraetere, C. (2008a). The challenge of nissology: A global outlook on the world archipelago - Part I: Scene setting the world archipelago. Island Studies Journal, 3(1), 3-16.

Depraetere, C. (2008b). The challenge of nissology: A global outlook on the world archipelago - Part II: The global and scientific vocation of nissology. Island Studies Journal, 3(1), 17-36.

Docastaway. (2016). What is Docastaway?. Docastaway. http://www.docastaway.com/pages/whatisdocastaway

Dodds, K., \& Royle S. (2003). The historical geography of islands. Introduction: Rethinking islands. Journal of Historical Geography, 29(4), 487-498.

https://doi.org/10.1006/jhge.2002.0406

Eco, U. (1995). The island of the day before. Secker \& Warburg.

Edmond, R., \& Smith, V. (Eds.). (2003). Islands in history and representation. Routledge.

Edquist, S., \& Holmén, J. (2015). Islands of identity: History-writing and identity formation in five island regions in the Baltic Sea. Södertörns Högskola.

Ellis, M. (2003). 'The cane-land isles': Commerce and empire in late eighteenth century georgic and pastoral poetry. In R. Edmond \& V. Smith (Eds.), Islands in history and representation (pp. 43-62). Routledge. https://doi.org/10.4324/9781003060260-4

Eriksen, A. (1995). Å lytte till historiens sus. Eller: Historie som emne for kulturforskningen. Kulturella Perspektiv, 4, 34-46.

Etymology Online (2019). Insular. Etymology Online. https://www.etymonline.com/search?q=insular

Fabian, J. (2002). Time and the other: How anthropology makes its object. Columbia University Press. (Original work published in 1983)

Fletcher, L. (2010). ' '.. some distance to go': A critical survey of island studies. New Literatures Review, 47-48, 17-34.

Genre. (n.d.). Wikipedia. https://en.wikipedia.org/wiki/Genre

Gibson-Graham, J. K. (1998, January 28-31). Islands: Culture, economy, environment [Conference presentation]. Island: Economy, society, and environment: Second Joint Conference, Institute of Australian Geographers and New Zealand Geographical Society, Hobart, Tasmania, Australia.

Gillis, J. (2001). Places remote and islanded. Michigan Quarterly Review, XL(1), 39-58.

Gillis, J. (2003). Taking history offshore: Atlantic islands in European minds, 1400-1800. In R. Edmond \& V. Smith (Eds.), Islands in history and representation (pp. 19-31). Routledge. https://doi.org/10.4324/9781003060260-2

Gillis, J. (2004). Islands of the mind: How the human imagination created the Atlantic world. Palgrave Macmillan.

Gillis, J. (2007). Island sojourns. Geographical Review, 97(2), 274-287. https://doi.org/10.1111/j.1931-0846.2007.tb00403.x

Gillis, J. (2012). The human shore: Seacoasts in history. University of Chicago Press.

Gotland.net. (2018a). Start. http://www.gotland.net

Gotland.net. (2018b). Resa. http://www.gotland.net/resa

Gotlands Tidningar. (2005, April 16). Hela Gotland. http://helagotland.se 
Great Belt. (n.d.). In Wikipedia. https://en.wikipedia.org/wiki/Great Belt Fixed Link

Gustafsson, L. (2002). Den förtrollade zonen. Lekar med tid, rum och identitet under Medeltidsveckan på Gotland. Nya Doxa.

Guteinfo. (2018). Gotlands största portal - $\quad$ turistinformation. http://www.guteinfo.com/?id=3469\&meny

Harms, E., \& Hussein, S. (2014). Remote and edgy: New takes on old anthropological themes. HAU: Journal of Ethnographic Theory, 4(1), 361-367. https://doi.org/10.14318/hau4.1.020

Hay, P. (2006). A phenomenology of islands. Island Studies Journal, 1(1), 19-42.

Heidegger, M. (1993). Basic writings. Routledge.

Heiniger, A. K. (2017). Insularity in the Old Norse Íslendinbgasögur. In A. Jennings, S. Reeploeg, \& A. Watt (Eds.), Northern Atlantic islands and the sea: Seascapes and dreamscapes (pp. 54-81). Cambridge Scholars Publishing. https://doi.org/10.3366/nor.2020.0208

Hellquist, E. (1980). Svensk etymologisk ordbok. LiberLäromedel/Gleerup. (Original work published in 1939)

Hodgen, M. T. (1931). The doctrine of survivals: The history of an idea. American Anthropologist, 33(3), 307-324. https://doi.org/10.1525/aa.1931.33.3.02a00010

Holmén, J. (2014). A small separate fatherland of our own: Regional history writing and regional identity on islands in the Baltic Sea. Island Studies Journal, 9(1), 135-154.

Homer (900 B.C./1919). The Odyssey. A.T. Murray (Trans.). William Heinemann.

Johannisson, K. (2001). Nostalgia: En känslas historia. Bonnier.

Kapchan, D. (ed.) (2014). Cultural heritage in transit: Intangible rights as human rights. University of Pennsylvania Press.

Källgård, A. (2007). Sweden, islands, and bridges. In G. Baldacchino (Ed.), Bridging islands: The impact of fixed links (pp. 251-260). Acorn Press.

Kinane, I. (2011). Revising the semiotic, surviving the symbolic: The desert island in popular 20th century fiction [Unpublished M. Phil. Thesis]. Trinity College.

Lakoff, G., \&. Johnson, M. (1980). Metaphors we live by. University of Chicago Press.

Lindh, M., \& Myte, L. (2009). Ett flytande paradis? En studie om hur tropiska öar framställs $i$ svenska resemagasin [Unpublished Bachelor thesis]. University of Kalmar, School of Communication and Design.

Lowenthal, D. (2007). Islands, lovers, and others. Geographical Review, 97(2), 202-229. https://doi.org/10.1111/j.1931-0846.2007.tb00399.x

Malm, C. (2013). A place apart? Debating landscapes and identities in the Shetland Islands. Coronet. Manguel, A., \& Guadalupi, G. (2000). The dictionary of imaginary places (3rd ed). Harcourt Brace.

Maspero, G. (1899). Histoire ancienne des peuples de l'Orient classique. [3], Les empires. Librairie Hachette et Cie.

Melville, H. (1849). Mardi: And a Voyage Thither. Richard Bentley

Nora, P. (1989). Between memory and history: Les lieux de mémoire. Representations, 26(Spring), 7-24. https://doi.org/10.2307/2928520

Oxford English Dictionary (n.d.). https://en.oxforddictionaries.com/

Pergament, D. (2007, October 7). The enchanted island that Bergman called home. The New York Times. https://www.nytimes.com/2007/10/07/travel/07cultured.html 
Privateislandsonline. (2019). Find your private island. Privateislandsonline. https://www.privateislandsonline.com/search?availability $=$ sale

Pugh, J. (2018). Relationality and island studies in the Anthropocene. Island Studies Journal, 13(2), 93-110. https://doi.org/10.24043/isj.48

Ronström, O. (2019). On the Meaning of Practicing Folk Music in the 21st Century. PULS: Journal for Ethnomusicology and Ethnochoreology, 4, 10-25.

Ronström, O. (2017, January 15-19). Remoteness, islands and islandness [Conference presentation]. REMOTE: Rethinking Remoteness and Peripherality, Longyearbyen, Svalbard.

Ronström, O. (2016). Öar och öighet. Introduktion till ö-studier. Carlsson.

Ronström, O. (2013). Finding their place: Islands as locus and focus. Cultural Geographies, 20(2), 153-165. https://doi.org/10.1177/14744744012445446

Ronström, O. (2011). In or on? Island Words, Island Worlds: II. Island Studies Journal, 6(2), 227-244.

Ronström, O. (2008a). A different land: Heritage production in the island of Gotland. Shima: The International Journal of Research into Island Cultures, 2(2), 1-18.

Ronström, O. (2008b). Kulturarvspolitik: Visby: från sliten småstad till medeltidsikon. Carlsson.

Ronström, O. (2003): “Oh! Island in the sun”: Telling the Gotlandic story. Journal of Indian Folkloristics, 5(1-2), 1-12.

Royle, S. A. (2007). Islands of the Irish coast and the "Bridging Effect". In G. Baldacchino (Ed.), Bridging islands. The impact of fixed links (pp. 203-218). Acorn Press.

Schalansky, J. (2010). Atlas of remote islands: Fifty islands I have not visited and never will. Particular.

Shetland Islands Council. (2018). Getting Here. http://visit.shetland.org/getting-here

Silverskär. (2019). Silverskär Islands. http://www.silverskar.ax/sv

Simmel, G. (1997). Bridge and door. In D. Frisby \& M. Featherstone (Eds.), Simmel on culture: Selected writings (pp. 170-173). Sage. (Original work published 1908)

Sparling, H. (2011). Cape Breton Island: Living in the past? Gaelic language, song, and competition. In G. Baldacchino (Ed.), Island songs: A global repertoire (pp. 49-64). Scarecrow Press.

Spurr, D. (1993). The rhetoric of empire: colonial discourse in journalism, travel writing, and imperial administration. Duke University Press. https://doi.org/10.1215/9780822398646

Statistics Norway. (2016). This is Svalbard 2016: What the figures say. https://www.ssb.no/en/befolkning/artikler-og-publikasjoner/this-is-svalbard-2016

Stratford, E., Baldacchino, G., McMahon, E., Farbotko, C., \& Harwood, A. (2011). Envisioning the archipelago. Island Studies Journal, 6(2), 113-130.

Swedish National Encyclopaedia. (n.d.). Uppslagsverket. https://www.ne.se/uppslagsverk

Tuan, Y. (1980). Rootedness versus sense of place. Landscape, 24(1), 3-8.

Visit Åland. (2018). www.visitaland.com

Visit Faroe Islands. (2018). Getting here. Visit Faroe Islands. http://www.visitfaroeislands.com/getting-here/

Visit Saaremaa. (2019). Saaremaa Tourism Brochures. Visit Saaremaa. https://visitsaaremaa.ee/en/info-2/saaremaa-tourism-brochures 